\title{
"All we need is Food..." Rural Politics and Peasant Struggles Amidst Unresolved Land Question in Southern Malawi
}

\author{
Justin Alinafe Mangulama \\ PhD Candidate. China Agricultural University. College of Humanities and Development Studies. Qinghua East \\ Road. Haidian District
}

\begin{abstract}
Peasants in Thyolo and Mulanje ${ }^{1}$ districts in Malawi have been at constant loggerheads with estate owners over the issue of land usage. With dwindling land-holdings among peasants chiefly due to high population growth and highly skewed land ownership (and usage) towards the tea estate owners, scores of peasants have managed to occupy idle tea estate lands to reproduce themselves. Livelihoods have relatively changed to this group of peasants, for the better. This study was done to understand the political processes surrounding access to tea plantation land and everyday peasant resistance initiatives. Using qualitative research design, results showed that a portion of peasants has managed to occupy idle estate land for over a decade now while majority still swim in land poverty. The number of new land occupants continues increasing with increased pressure from poverty. The peasants 'sugar-coat' their occupation by occupying only idle estate land, and forming local-level mechanisms to deter other peasants from vandalizing estate crops. The occupied lands have bred 'village-rich' group of people who have acquired much wealth (at village level) from the land while others barely survive. With widespread insecurity of tenure in the occupied lands, the study recommends formal restitution of idle land to locals as a poverty reduction initiative.
\end{abstract}

DOI: $10.7176 / \mathrm{DCS} / 10-5-05$

Publication date:May $31^{\text {st }} 2020$

\section{Setting the Scene}

At 5 am early in the morning, Paundi (pseudo name) wakes up to his newly acquired 4 hectares of land from Comforzi ${ }^{2}$ estates in Chibwana village, Thyolo. He has been cultivating in a land belonging to the estate for more than 11 years. He harvests a minimum of 50 bags of 50 kilograms each every year. Apart from maize he grows groundnuts, sugarcane, cassava, sweet potatoes, bananas, cowpeas and millet. He has been able to buy land from another area, bought cattle to diversity agriculture, built his new house from the harvest and also assisted his family and dependents in their education. Food shortage is no longer his problem. Paundi is not the only one doing cultivation in idle estate lands, popularly known as 'multiparty'. Scores of people around the tea estates ${ }^{3}$ in Thyolo have managed to encroach the tea estates due to pressure in landlessness and increased poverty. Chinigo (2016) reports that almost $70 \%$ of prime land area in Thyolo district is covered by tea estates ${ }^{4}$. Majority of rural Malawians in Thyolo continue to suffer from land poverty whilst huge thatches of land continue to remain idle for decades. The Peoples Land Organization (PLO) has been on an ambitious campaign to renegotiate land deals with Malawi government. Though PLO had not achieved its three main objectives, local peasants have been motivated to encroach the estates and begin their cultivation. Encroachment is not a new phenomenon in southern Malawi. In 1953, estate owners in southern Malawi killed at least 10 people, in what is termed as 'the Teneti Massacre' (Chinigo, 2016)'. However, peasants continue to devise new strategies to encroach land. But why is it that some peasants have managed to resist the continued alienation from land in Thyolo and Mulanje while others have not? Who are these peasants that have managed to encroach and cultivate? What have been the narratives from the estate owners? How have the peasants maintained reproducing themselves in the land areas belonging to the estates? How is the security of tenure achieved? This paper responds to these pertinent issues and adds insights to peasant resistant studies using the case of southern Malawi.

\section{Theoretical Framework}

It has been argued by many that politics and resistance cannot be tackled in isolation. Wolf (1968), Scott (1976), Scott (1985), Scott (1998), Kerkvliet (2009), and O'brien (2006) have tacked the question of resistance in peasant societies, agrarian movements, political problems and other socio-political and economic issues at length. Lasswell's (1958) puts into perspective the word politics as who gets what, when and how. Thus Kervliet argues the question of resistance cannot be understood without understanding the political structure of the system in which

\footnotetext{
${ }^{1}$ Thyolo and Mulanje are the two tea-growing districts in southern Malawi. Huge thatches of land are used to grow the same. The estates are largely foreign owned. In the article, Thyolo and Mulanje districts; and Southern Malawi will be used interchangeably.

${ }^{2}$ A Tea Estate Company in Southern Malawi

${ }^{3}$ Estate is being referred in this article as a huge plantation farm in Southern Malawi. It can range from 500 hectares-3500 hectares of land

${ }^{4}$ The tea estate companies own huge thatches of land. It is believed that around $40 \%$ of the land remain 'idle' and it is this land that peasants clos to the estates seek solace in for agricultural activities
} 
resistance occurs. And, politics as elaborated by him is about 'control and allocation, production and use of resources and values and ideas underlining those resources.' Foucault (1978:93) saw the resistance as an essential element to counter the power, thus arguing, 'where there is a power, there is resistance.'

Seymour (2006) defines resistance 'intentional and hence conscious acts of defiance or opposition by a subordinate individual or a group of individuals against a superior individual or a group of individuals': James Scott (1985) perhaps one of the influential theorist on peasant resistance at the present time, in his in-depth and valuable study in Malaysia titled 'Weapons of the Weak' argues that it is everyday struggles of collective individuals which help them (peasants) achieve their goal, than occasional episodes and rebellions. However, Scott has been criticized by Walker (2008) for projecting or defining peasants as defensive and disempowered who are not able to change the conditions. In other words, are like bags of potatoes who need to be moved.

Following the path of Scott in understanding resistance, Kerkvliet (2009) in his study 'Everyday Politics of peasants. The study is very important in the context to understand resistance. Kerkvliet builds upon Scotts' theory and takes us to understand how people contest, accept, challenge and adjust existing norms 'over allocation of resources.' They do it by subtle and mundane, however often unorganized way to get their demands met. Unlike official and advocacy politics- the two other forms of peasant politics- the people who do everyday politics do not know they are doing politics, with no organization and structure in place.

On the other hand; O'brien and $\mathrm{Li}$ (2006) in their study on peasant resistance in China offer a very interesting variant of Scott and Kerkviliet's work, which came to be known as 'rightful resistance'. They argue that peasants invoke the promises provided by the leaders and the constitutional laws to demand their rights through unstructured, unorganized in the way that Scott and Kerkvleit saw everyday peasant politics, but it is not covert, it is overt resistance. While the everyday forms of resistance was observed as disguised, anonymous, quiet and mundane, rightful resistance was observed as more open, public, and noisy (O’Brien, 2013).

\section{Research Methodology}

This study was about understanding the processes and resistance over access to arable land in southern Malawi. The study employs a quantitative research design. Due to the nature of the topic, most questions posed in this study could not be explained in figures.

\section{Description of the Study Area}

Malawi is a landlocked, low-income country located in the South-Eastern part of Africa with a rapidly expanding population of which $84 \%$ are rural; and $80 \%$ are small holder farmers (Kishindo, 2004; NSO, 2018). Most rural families experience poverty. Most of these families rely on small parcels of densely cultivated land for their livelihoods and this presents them as vulnerable to the impacts of natural disasters that include floods and droughts. Land poverty is rampant in southern Malawi where huge thatches (more than 70 percentage) of prime land is owned and controlled by large-scale plantation farmers (Chinigo, 2016). Many local people have been alienated from the land and its associated resources, a phenomenon which some scholars have termed a 'selective but incomplete capitalism.' With majority destitute for livelihoods, land encroachment in southern Malawi is common. The study was conducted in Chibwana and Chaona villages, Traditional Authority (TA) Nchilamwera in Thyolo District, Malawi. The study villages were selected because they were located outside Comforzi and Small-Holder ${ }^{1}$ Tea Estate in Thyolo where many peasants fighting to repossess idle land in Thyolo dwell. Majority of people within the tea estate surrounding villages eke their livelihoods through small scale farming, with few working in the tea estates as labourers. One is, therefore, likely to find a rich source of landless or near landless people who could be studied in relation to the objectives of this study.

\section{Target Population, Sampling Method and Sample Size}

The respondents for this study were inhabitants of Chibwana and Chaona villages and other peasant farmers that have managed to encroach large-scale tea estate lands. This included both landed and landless. The study also collected information from selected key informants like District Land Officials, Representatives from Peoples Land Organizations, Senior Estate Tea Managers, and Village leaders. The sampling technique for peasants and key informants was snow bow non-probability sampling. This was done to identify respondents that had useful and relevant information pertinent to this study. The interviews were done until saturation point was reached.

\section{Data Collection Instruments}

Data collection took place over a period between January and September 2018. The data was collected through interview guides; observations; informal discussions; in depth interviews and transect walks in the villages. Apart from primary data sources, the study also utilized some secondary data sources both from the village, estate companies, government and published articles on related themes under study.

\footnotetext{
${ }^{1}$ By the time of the research, Muli Brothers Limited, a Malawian conglomerate, owned Small-holder Tea Estate. Comforzi and Nansonia wee all foreign owned.
} 


\section{Occupation of Land in Estates in Southern Malawi}

This study finds out that the occupation of the estate land is not actually led by social movements like the PLO${ }^{1}$. What the PLO achieved was to motivate the peasants that retaking part of the land from the estates was possible. On $15^{\text {th }}$ March 2014, the PLO led thousands of peasants to occupy idle land in the estates. Although the state security over-powered the PLO, locals have individually managed to subtly encroach the idle land. Laments one peasant:

"These are individual peasants who just start cultivating the estate land. When they are successful, a whole lot of peasants follow suit, making the encroached estate land bigger and bigger. It is not people from one village that partake this exercise. Rather, where a portion of land is available, people from different villages tip each other to occupy such type of land and start cultivating that idle land until it is used up.'

Village leader for Chibwana village had this to say:

"There is plenty of idle land close to my village. I cannot explain to you how big it is. I can show you if you wish. Not all my village subordinates have managed to occupy land in the estates. If you look at those peasants, some come from far away areas. News spread that people of Chibwana area sharing land and other people from far away villages took opportunity to have a share of the land...'

Landholdings in the newly established fields range from 1-5 hectares per household. Factors determining size of the occupied land holdings are in two fold: the household capability to clear out the bush for cultivation purposes; and the availability of the idle estate land being shared by the peasants. In many of the occupied lands, many female-headed households constituted a larger proportion of the new occupants. The study could not quantify the number of farmers occupying the estate lands due the nature of the occupation itself. Though the researcher dwelled much on the two villages under study, the occupants were from other villagers far from the estates.

'I have family land that was passed over to me by my great grandparents. However, it is really small. I have 6 children. I cannot grow enough from this piece of land to feed the whole family. I had no any other choice but to follow others who were encroaching the idle estate land' (Peasant Farmer, Chaona Village)

This finding agrees with many scholars like Kanyongolo (2005) and Chinsinga (2011) that with population increase and dwindling landholdings in southern Malawi, the people are left with no option but to encroach estate idle land and start cultivations.

\section{Peasant Resistance techniques}

There has been various techniques peasants in Malawi have utilized to resist continued alienation from estate lands.

\section{i.Village Committees}

One of the techniques is that the peasants have reorganized and created committees with an aim to protect the estates from fire that might harm the estate crops (tea and macadamia nuts).

'Peasants in Thyolo and Mulanje have managed to device ways for continued reproduction on the new estate lands. They are aware that the land is legally not theirs. However, they are destitute for livelihoods. They occupy unused land belonging to the estates; at the same time being mindful of not compromising the already sour relationships between the estates and the peasants. They manage to do this in two ways: in the first place, they have formed firebreaks that have been there to protect the plantations. Secondly, they have created a village committee responsible for monitoring the day-to-day activities of the peasants.' Peasant farmer, Chaona village.

As explained earlier in the article, the peasants have massively pounced on idle land. The committees' duty was to make sure that no peasants, despite how desperate they are go beyond the unused land to destroy tea or macadamia nuts for the sake of creating farmland. This has been in practice for years and it seems working.

\section{ii.Creation of Fire Breaks}

The people in the study villages were all aware that they did not legally own the land. At the same time their livelihoods were hugely hinged from agricultural activities from the estate idle land. While they were mindful of this, they sugarcoat the already compromised relationships between themselves and the estate owners. They did this by creating firebreaks between their farms and the plantation crops. They did this not to stir more anger from the tea estate management.

\section{iii.Subtly Removing Trees from the Idle Land}

The local agreement between the estates and the surrounding communities on the use of idle land is that the people should be the daily watchmen. They should make sure people are not destroying estate crops including trees. It is however common knowledge that the estates in Thyolo and Mulanje cannot utilize all the land. Most of the land that has neither tea nor macadamia nuts has huge Pine trees planted on the land. So what the people did was to cut the trees at night and at a later stage share the same land for cultivation, claiming it was idle.

'At night, some peasants cut the trees. One by one, land is being cleared. After an area has been cleared out, they share the land and start cultivating crops. When the estate management asks us about the ordeal, we respond to them that we are neither official watchmen for estate crops, nor do we watch over at night that were responsible

\footnotetext{
${ }^{1}$ Peoples Land Organization (PLO) is the local NGO in Thyolo and Mulanje that advocates for land restitution from the estate owners to local people.
} 
for the act. In so doing we win the land and start our cultivation.'

iv.Peasants Take Advantage of Change in Estate Management

The former managers of the estates continuously utilized idle estate land for trees. They had tree gardens right in the estates. Once some were cut, many were planted instantly.

'You see there have been changes in the way the estates are managing the land. When I was young land could not stay idle for even 2 years. But now you see land staying idle for more than a decade with nothing on it. This has ignited land-hunger peasants to encroach for food production.'

\section{v.Open Resistance by some Peasants}

In a desperate quest for livelihoods, some peasants openly resist to move from the land. They openly tell state security agencies or estate managers that they will never leave the estate land. Some get arrested for using the estate land. Just after jail term, they go back to the land again.

"For me it is better I die that stop cultivating from the 'multiparty"' land. Since I occupied this land, my grandchildren (who are orphans) can be taken care off. I am 70. If they kill me they can proceed. I have told the police officers at Thyolo even the estate managers the same story over and over again. I am not afraid of them. This land belonged to our forefathers. Enough is enough.'

How social differentiation operates to dictate who owns/not own the reclaimed land?

Both men and women have been involved in the occupation of tea plantation land. Classes have however emerged from the occupied lands. These have included the rise of village rich, utilizing the estate land to occupy more assets than the rest of the peasants. Chikhawo (not real name) had this to say:

I managed to occupy 5 hectares of land from the estates since the year 2007. From the 100 bags I harvest every year from the estate lands, I have managed to build my house with iron sheets. This would have been impossible, as I am not employed in any company in government. I completed MSCE level but got no employment. This has boosted my income. From the same harvest, I have also bought a piece of land in another village very far from here. I paid Mk1, 200,000² for that piece of land. I rent it out to other villagers closer to that place because I cannot be able to farm it on my own since its very far. However, if the worse come to the worst here, I will be able to go to that place to continue my farming career.

Village tigers ${ }^{3}$ owning multiple parcels of land have also emerged. They usually have privileged information on where other peasants are sharing land; they can buy off other peasants parcels; employ other labour to work on their parcels of land. This has led to the emergence of wealth groups from the reclaimed lands.

\section{Narratives from the Estates Owners}

The estates in Thyolo and Mulanje have responded in multiple ways to the occupation of the peasants. In areas where people have managed to encroach for years, the estates have either built trenches to deter the peasants from further encroachment.

\section{i.State Security}

In several occasions we have used state security to arrest people who have encroached our land. This is our land, legally, whether idle or not.

\section{ii.Local-Level agreements between the estates and communities}

In Chibwana village, the estate and local people came to a consensus that the local people use part of the land belonging to the estate. This was a verbal agreement between the local chiefs in Chibwana area and the tea estates authority.

\section{iii.Construction of Trenches and Barriers}

In other parts of the estates there has been construction of deep trenches to act as barriers. In these areas, peasants are totally banned any access into the estate land and its associated resources like firewood, fruits, grass, etc.

Security of Tenure in the newly occupied Land

The people occupying estate lands in Thyolo and Mulanje are able to meet their livelihoods needs from the cultivation of crops and animal feeds from this land. However, it needs to be mentioned that they still consider that the land is not theirs. This research found out that there are investments that they cannot do on this land. Investments in irrigation equipment to boost yields for instance is hampered by the fear that at any time they might loose the land, hence all the investment might be lost. One peasant had this to say:

"I cannot practice conservation agriculture on the occupied land. Its quite intensive and lots of work is needed. I fear risking loosing all the hard work. Sometimes the estate security guards wait until our crops are about to be harvested then they slash all of them to the ground. We don't back down. We plant again come the next planting season. For my own land given to me by my great grandparents, I cultivate with all the assurance that I will harvest. In the occupied lands we are not certain."

\footnotetext{
${ }^{1}$ The Peasants in Chaona village have termed the occupied land 'multiparty' land. This is the case because there are so much variety of peasants cultivating there. Rich villagers, poor, estate workers, and many other personalities fro other villages. This co-existence for a common goal has made them term the occupied land 'multiparty.

${ }^{2} \mathrm{Mk} 1,200,000$ is equivalent to $\$ 1,637$ at $1 \$=\mathrm{Mk} 733$ rate during the time the article was being written

${ }^{3}$ Ermegency of Village Rich from the reclaimed land
} 
One would therefore argue that without proper documentation on the use of idle land in southern Malawi, there still exist opportunities being lost.

\section{Conclusion}

Resistance is rampant from the tea growing areas of Thyolo and Mulanje in southern Malawi especially due to dwindling landholdings and increased poverty levels among the peasants. Encroachment into idle estate land has brought mixed outcomes. While some villagers have managed to accrue multiple parcels from the multiparty and harvesting bumper yields with the help of hired labour, some just produce for subsistence. Major drawback on the part of the peasants has been insecurity of tenure. Peasants 'sugarcoat' their tense relationship with estate owners, at the same time subtly creating ways to get more idle land. The study would recommend formal restitution of unused estate land to the peasants especially land that has stayed idle for decades as a drive to poverty reduction.

\section{REFERENCES}

Chinigo, D (2015). Depeasantization and Land Reclamation Movements in Malawi. Journal of African Affairs. $115 / 458,97-118$

Chinigo, D (2016). Rural Radicalism and the Historical Land Conflict in the Malawian Tea Economy

Chinsinga, B. (2011), The politics of land reforms in Malawi: the case of the Community Based Rural Land Development Programme (CBRLDP). Journal of International Development, 23, 380-393.

Kanyongolo, F. E. (2004), Land occupations in Malawi: challenging the neo-liberal legal order. In S. Moyo and P. Yeros (eds), Reclaiming the Land: The Resurgence of Rural Movements in Africa, Asia and Latin America. London: Zed Publishers, pp. 118-141.

National Statistical Office (2018). 2018 Malawi Population and Housing Census. Preliminary Report. Zomba, Malawi

Scott J. Freedom and Freehold: Space, People and State Simplification in South East Asia. Asian Freedoms: The Idea of Freedom in East and Southesat Asia. Eds. David K, Anthony R. Cambridge UP, 1998. 37-64

Scott J. The Moral Economy of the Peasant: Rebellion and Subsistence in South East Asia. New Haven and London: Yale University Press, 1976

Scott J. Weapons of the Weak: Everyday Forms of Resistance. New Haven and London: Yale University Press, 1976

Kerkvliet B. Everyday Politics in Peasant Societies (and Ours). Journal of Peasant Studies, 2009,36: 227-243

O’Brien, Li L. Rightful Resistance in Rural China. Cambridge University Press. 2006

Wolf, E. Peasants Wars of the Twentieth Century. University of Oklahoma Press, 1969 